УДК 376.4.062.3

DOI https://doi.org/10.26661/2310-4368/2021-2-10

\title{
ФОРМУВАННЯ ЕМОЦІЙНИХ РЕАКЦІЙ НА НЕУСПІХ У ДІТЕЙ ІЗ ЗАТРИМКОЮ ПСИХІЧНОГО РОЗВИТКУ
}

\author{
Соколова Г. Б. \\ доктор психологічних наук, дочент, \\ доиент кафедри дефектології та фізичної реабілітації \\ Державний заклад «Південноукрайнський національний педагогічний університет \\ імені К. Д. Уиинського» \\ вул. Фонтанська дорога, 4, Одеса, Украӥна \\ orcid.org/0000-0002-9913-1814 \\ absokolova@ukr.net
}

Ключові слова: дитина з особливими освітніми потребами, діти із затримкою психічного розвитку, адекватна емоиійна реакиія, позитивне ставлення, ситуація успіху/неуспіху, навчання.
Стаття присвячена проблемі, яка має практичне та науково-теоретичне значення, оскільки специфіка організації освіти дітей з особливими потребами може бути обумовлені не тільки обмеженням здоров'я, але й соціокультурними чинниками. Численні зарубіжні та вітчизняні дослідження довели, що діти, які мають загострений страх невдач та низький рівень домагань, демонструють низькі результати, а коли процедура навчання зменшує страх невдачі, показникиінтелектуального та психічного розвитку значно покращуються. Основна дослідницька мета дослідження полягала у застосуванні методу лонгітюдного дослідження емоційних реакцій дітей із затримкою психічного розвитку (ЗПР) на неуспіх та формування адекватних реакцій, які не призводять до відмови від виконання завдання 3 опорою на провідні індивідуально-психологічні характеристики дитини із ЗПР. Для досягнення мети було розроблено та застосовано оригінальний авторський алгоритм дослідження та подальшого формування адекватних емоційних реакцій дитини на ситуації неуспіху в умовах навчання. Дітям пропонувалися три види занять: ігрового, довільного (вольового) та інтелектуального спрямування.

Виявлено, що лонгітюдна форма дослідження є найбільш ефективною, оскільки процес формування та закріплення адекватних емоційних реакцій дітей із ЗПР на ситуації неуспіху є довготривалим, ефективність якого суттєво посилюється залученням до роботи батьків. Показано, що між змістовною стороною завдання та ставленням дітей до ситуацій неуспіху існує зв'язок, а формування адекватних емоційних реакцій на неуспіх його закріплює. В ігрових завданнях всі діти достатньо легко реагували на ситуації неуспіху, самостійно та із задоволенням виправляли помилки, а при виконанні довільного (вольового) та інтелектуального завдань у дітей проявився ширший діапазон індивідуально-психологічних особливостей. Найбільш сильно страх неуспіху впливає на результати виконання інтелектуальних завдань, оскільки пов'язаний із очікуванням негативного результату. Тому важливою умовою формування успішного, емоційно забарвленого навчання для дітей із ЗПР є завершення будьякого кроку навчальної діяльності тільки на позитивній емоції. 


\title{
FORMATION OF EMOTIONAL REACTIONS TO FAILURE IN CHILDREN WITH DEPRIVATION OF MENTAL DEVELOPMENT
}

\author{
Sokolova H. B. \\ Doctor of Psychological Sciences, Associate Professor, \\ Associate Professor at the Department Defectology and Physical Rehabilitation \\ South Ukrainian National Pedagogical University named after K. D. Ushynsky \\ Fontanska Doroha str., 4, Odesa, Ukraine \\ orcid.org/0000-0002-9913-1814 \\ absokolova@ukr.net
}

Key words: child with special educational needs, children with mental retardation, adequate emotional reaction, positive attitude, situation of success / failure, learning.

\begin{abstract}
The article is devoted to the problem, which has practical and scientifictheoretical significance, as the specifics of the organization of education of children with special needs may be due not only to health limitations, but also socio-cultural factors. Numerous foreign and domestic studies have shown that children who have an acute fear of failure and a low level of harassment give low results, and when the training procedure reduces the fear of failure, the indicators of intellectual and mental development are significantly improved. The main research goal of the study was to apply the method of longitudinal study of emotional reactions of children with MR to failure and the formation of adequate reactions that do not lead to failure to perform the task based on leading individual psychological characteristics of a child with CPD. To achieve this goal, an original author's algorithm of research and further formation of adequate emotional reactions of the child to the situation of failure in the learning environment was developed and applied. Children were offered three types of activities: play, voluntary (volitional) and intellectual orientation.

It was found that the longitudinal form of research is the most effective, because the process of forming and consolidating adequate emotional reactions of children with MR to the situation of failure is long-term, the effectiveness of which is significantly enhanced by parental involvement. It is shown that there is a connection between the content of the task and the attitude of children to situations of failure, and the formation of adequate emotional reactions to failure fixes it.

In game tasks, all children easily tolerated situations of failure, independently and with pleasure corrected mistakes, then when performing arbitrary (volitional) and intellectual tasks, children showed a wider range of individual psychological characteristics. The fear of failure has the greatest impact on the results of intellectual tasks, as it is associated with the expectation of a negative result. Therefore, an important condition for the formation of successful, emotionally colored learning for children with MR is the completion of any step of educational activities only on positive emotions.
\end{abstract}

Постановка проблеми. Поняття «дитина 3 особливими освітніми потребами», яке широко використовується як у соціальному, так і в науково-професійному сенсах, дозволяє педагогам та психологам не тільки визначати шляхи задоволення цих потреб, але й екстраполювати їх на всі категорії та групи особливих дітей. Науково-теоретичний аспект цієї проблеми важливий тому, що розширює межі між віковою та спеціальною психологією, між нормативністю та порушеним розвитком. Ця теза важлива, оскільки освітні потреби дитини можуть бути обумовлені не тільки обмеженням здоров'я, але й низкою соціокультурних чинників (Л. І. Прохоренко [3]). Успіхи дітей при виконанні будь-яких завдань (навчальних, комунікативних, мовленнєвих, ігрових тощо) часто визначаються не тільки їхнім інтелектуальним розвитком, запасом знань, але й мотивованістю, емоційними реакціями, соціальним досвідом, сформованими рисами характеру. 
Ось чому тема, яка піднімається в даному дослідженні є актуальною.

Дослідження зарубіжних вчених довели, що діти, які мають загострений страх невдач та низький рівень домагань, в умовах тестування давали низькі результати, а коли процедура психодіагностичного обстеження організовувалася таким чином, що страх невдачі максимально зменшувався, показники їхнього інтелектуального та психічного розвитку були значно кращими (A. Ziegler [5]). Тобто, низькі тестові показники можуть свідчити не стільки про низькі інтелектуальні показники, скільки про процедурно-методичні помилки фахівця, який організовує це дослідження. Більшість дітей із ЗПР к молодшому шкільному віку вже мають сформований особистісний комплекс: невпевненість в собі, страх невдачі та неадекватну реакцію на неї, слабку мотивацію досягнення мети та ін. Часто психолого-педагогічне вивчення дітей із ЗПР $\epsilon$ однократними, а особливості уявлення про їх особистісний розвиток проявляються у формувальному експерименті (В. І. Лубовський [2]), який не завжди дозволяє: фіксувати або регулювати емоціональні реакції дітей, враховувати емоційний вплив фахівця на дитину в процесі надання їй допомоги під час виконання завдання, оскільки дитина, довго не розуміючи завдання, може не тільки переживати негативні емоції, але й внутрішньо відмовитися від виконання завдання. Ось чому найбільш доречною формою вивчення емоційної сфери дітей $з$ особливими освітніми потребами є лонгітюдне дослідження, яке, на думку Й. Шванцари, дозволяє ретельно проаналізувати особливості взаємозв'язків між окремими компонентами їх особистості та чинниками розвитку [4].

Мета статті: презентація результатів лонгітюдного дослідження емоційних реакцій дітей із ЗПР на неуспіх та формування адекватних реакцій, які не призводять до відмови від виконання завдання.

Виклад основного матеріалу дослідження 3 обгрунтуванням отриманих наукових результатів. В лонгітюдному дослідженні, перший етап якого триває протягом 2020-2021 років прийняли участь 30 дітей із ЗПР 6-7 років. Оскільки формування у дітей з особливими освітніми потребами адекватних емоційних реакцій не можливе без участі батьків, вони теж були залучені до роботи, інколи приймали участь в емпіричному дослідженні та завжди отримували інструкції з закріплення досягнень дитини вдома.

Дослідження проводилося с кожною дитиною індивідуально. Ми пропонували їм наступні завдання: вставні картинки, обведення по контуру фігур «дім», «ялинка», «кораблик», прості лічильні операції в межах індивідуальних можливостей кожної дитини.

Як показало спостереження, перше завдання супроводжувалося позитивними емоціями, сприймалося дітьми як гра, викликало зацікавленість; друге завдання не залежало від інтелектуального розвитку, а моторних порушень та ліворукості в експериментальній групі не було. Останне завдання було пов'язане 3 інтелектуальним розвитком та індивідуальними можливостями дитини в оволодіння лічильними операціями.

Для проведення емпіричного дослідження емоційних реакцій дитини на ситуації неуспіху нами був розроблений спеціальний дослідницький алгоритм дій, який містив наступне:

- створення ситуацій штучного успіху (коли він не залежить від дитини, ії дій та реакцій);

- навчання дитини конкретній операції в ситуації успіху (досягнення акцентуються, недоліки ігноруються);

- звертання уваги дитини на недоліки виконання певної операції, але без критики, із похвалою за старанність та наполегливість;

- м'яке введення у діяльність дитини елементів неуспіху (ми звертали увагу на помилки, але не сварили дитину і не хвалили іii, позбавляючи таким чином відчуття успіху);

- спільний із дитиною пошук засобів досягнення успіху, виправлення помилок;

- самостійне виправлення помилок;

- створення ситуації неуспіху, виправлення помилок та очікування успіху;

- введення такої важливої змінної як оцінювання та створення ситуації успіху дитини із отриманням найвищої оцінки;

- створення ситуації неуспіху та відсутність позитивної оцінки без отримання негативної. Пошук виходу із ситуації;

- виконання завдання із обговоренням якості його виконання. Спроба самостійного оцінювання результатів та виправлення помилок.

Основна мета дослідницької роботи полягала у виявленні деяких індивідуально-психологічних особливостей дітей із ЗПР при виконанні різних завдань та навчання їх адекватному реагуванню на ситуації неуспіху.

Як ми відмічали вище, умовно усі завдання розподілялися на ігрові, довільні (вольові) та інтелектуальні: ми припустили, що, починаючи роботу з ігрових завдань, цікавих та привабливих для дітей із ЗПР, на першому етапі легше буде сформувати адекватну реакцію на неуспіх. В подальшому ми сподівалися на перенос адекватних форм реагування на інші форми роботи. Включення завдань на формування довільності мало показати роль таких особистісних характеристик як наполегливість, старанність. Ми очі- 
кували, що найбільш сильні негативні реакції у дітей із ЗПР будуть викликати завдання інтелектуальної спрямованості.

Аналіз проведеної роботи показав наступне. Як ми і припускали, найбільш успішно формування адекватних емоційних реакцій на ситуацію неуспіху проявлялося при виконанні ігрових завдань. Умовно ми виділили дві групи дітей за двома типами поведінкових реакцій. У першу групу (15 осіб) були включені діти із внутрішньою мотивацією, у другу групу (15 осіб) - діти із домінуючої зовнішньою мотивацією. Перший тип реакцій (1 ГР) характеризувався вираженим інтересом до змістовного боку завдання, який мотивував дитину до виконання; неуспіх в ігрових завданнях частково гальмував їх виконання, але після паузи прагнення дитини продовжувати роботу відновлювалося. При реакціях 1 ГР оцінювання не мало особливого значення для дитини. Вже через 2 заняття ми констатували наявність адекватних емоційних реакцій на неуспіх в процесі ігрової діяльності.

Реакції другого типу (2 ГР) виникали як відповідь на зовнішнє стимулювання дитини. Інтерес до завдання, який виникав на початку роботи, швидко зникав, діти потребували підтримки. Активно працюючи над ігровим завданням в умовах успіху, діти швидко втрачали інтерес, коли виявлявся неуспіх, але, орієнтуючись на наші реакції, вони швидко навчились адекватно реагувати на неуспіх та виправляти помилки. Наявність адекватних емоційних реакцій на неуспіх в процесі ігрової діяльності було сформовано через 4 заняття.

Виконання завдання на розвиток довільності передбачало обведення фігур та вимагало від дітей таких особистісних характеристик як зосередженість, цілеспрямованість, старанність. Умовно ми виділили три групи дітей за трьома типами поведінкових реакцій. У першу групу (1 Д) увійшли діти із помірною зовнішньою стимуляцією (8 осіб), у другу (2 Д) - діти із сильною зовнішньою стимуляцією (13 осіб) та у третю (3 Д) - діти із сильною зовнішньою стимуляцією, схильні до співробітництва 3 дорослим (9 осіб).

При реакціях 1 Д діти проявляли інтерес та бажання навчитися обводити фігури, вони адекватно реагували на труднощі, які виникали в процесі роботи, та орієнтувалися на наші реакції. Ситуації неуспіху їх засмучували, але перемагало бажання виправити помилки та отримати високу оцінку. Наявність адекватних емоційних реакцій на неуспіх в процесі довільної діяльності було сформовано через 5-6 занять.

При реакціях 2 Д у дітей виникала короткочасна зацікавленість завданням, але при перших же невдачах вона швидко згасала. Діти не проявляли самостійних зусиль, обводячи фігури, але, адекватно реагуючи на успіх та похвалу, деякий час продовжували виконання завдання. Ми були вимушені стимулювати зовні їхню активність. Ситуації неуспіху дезорієнтували активність дітей, вони не хотіли виправляти помилки, але дуже раділи успіху. Зовнішне оцінювання результатів діяльності виявилося важливим стимулом для виконання завдань на довільність. Наявність адекватних емоційних реакцій на неуспіх в процесі довільної діяльності в групі 2 Д було сформовано через 8-10 занять.

При реакціях 3 Ду дітей було відсутнє бажання працювати навіть у ситуаціях успіху: вони майже не реагували на нашу похвалу та переключали увагу на щось інше. На стадії діяльності без похвали, але й без осуду їхня діяльність вже порушувалася. Не залежно від якості роботи неуспіх призводив до відмови від виконання завдання. Для формування адекватної реакції на неуспіх в цій групі була потрібна сильна зовнішня стимуляція (ми доповнювали стандартний набір трафаретів), багаторазове проходження усіх етапів нашого алгоритму, тривалі паузи для подолання психічного «перенасичення». Наявність адекватних емоційних реакцій на неуспіх в процесі довільної діяльності в групі 3 Д було сформовано через 20 занять.

Виконання інтелектуального завдання було найскладнішим для дітей із ЗПР та максимально індивідуалізованим. Діти рахували по 1 та по 2 в межах 6, а ті, для кого оволодіння усною лічбою було складним завданням, здійснювали ці операції, спираючись на зовнішній матеріал. Для подолання ситуації неуспіху ми пропонували дітям виконувати складне для них завдання самостійно, повторно або з нашою допомогою, що сприяло виправленню помилок. У випадку переживання труднощів дітям надавалася підтримка та допомога. Нами було виділено дві групи дітей (зі сформованою самооцінкою - 11 осіб та із несформованою самооцінкою - 19 осіб) та два типи емоційних реакцій. При реакціях $1 \mathrm{IH}$ діти раділи успіху у випадках співпадіння нашої оцінки їхньої діяльності із внутрішнім відчуттям успіху: ми хвалили дітей, а потім питали: «А ти правильно виконав це завдання?». Діти 1 IH упевнено відповідали: «Так!» та демонструвати бажання навчатися виконанню інтелектуальних завдань. Якщо ми хвалили дитину, а завдання було виконано неправильно, виникало здивування та збентеження, а на наше питання чи правильно виконано завдання, дитина відповідала «Не знаю» або «По-моєму, ні». На наш погляд, поява таких відповідей може свідчити про формування адекватної самооцінки та аутентичні емоційні реакції на успіх або неуспіх. Важливо, що поступово змінювалися реакції дітей на неуспіх як на тимчасовий стан, 3 
якого можна вийти, звернувшись за допомогою до дорослих або додатково виконавши завдання на конкретному матеріалі. Завдяки такому підходу виконання завдань з усної лічби поступово втрачало для дітей своє негативне значення. Наявність адекватних емоційних реакцій на неуспіх в процесі виконання інтелектуальних завдань в групі 1 IH було сформовано за 5-6 занять.

При реакціях 2 IH при сприйнятті успіху та неуспіху діти орієнтувалися виключно на наші реакції. Позитивним $\epsilon$ те, що вони виходили із ситуацій неуспіху не відмовляючись від діяльності, зверталися за допомогою або виконували завдання на конкретному матеріалі, але подібні реакції були нестійкими та при повторному неуспіху відмовлялися від роботи або демонстрували небажання продовжувати. Крім того, у цій групі ситуації неуспіху суттєво підвищували кількість помилок навіть у доступних за складністю прикладах. Формування адекватних емоційних реакцій формувалося довше за всі інші форми роботи - за 18-20 занять.

Особливе місце в проведеному дослідженні займала робота 3 батьками, без якої ефективність та результативність суттєво зменшувалися. Основний зміст участі батьків полягав у закріпленні сформованих під час експериментальної роботи емоційних реакцій дітей. Оскільки батьки завжди були присутні на заняттях, вони повторювали його вдома, завершуючи на тому ж етапі, що і ми. Бесіда з батьками показала, що завдання ігрового змісту засвоювалося дітьми добре, вдома емоційні реакції, які їх супроводжували, майже не потребували додаткового закріплення, вони були відпрацьовані на занятті. Довільне та інтелектуальне завдання викликало у батьків труднощі: вони не завжди могли відтворити те, що ми проводили із дітьми під час експериментальної роботи та діти приходили на наступні заняття без закріплених бажаних емоційних реакцій.

Будь-які труднощі ми обов'язково обговорювали та аналізували з батьками, виділивши їхні головні помилки: недотримання інструкцій психолога (робота завжди мала завершуватися на позитивній емоції, а батьки інколи переривали iii на негативному зауваженні, що призводило до зникнення бажаного позитивного ефекту) та бажання форсувати алгоритми роботи вдома, що призводило до перевтомлення та роздратування дитини. Ці зауваження важливі при організації дитини 6-7 років і при типовому розвитку, а у дітей із затримкою психічного розвитку $є$ особливо значимими.

В таблиці 1 ми відобразили етапи проведеної роботи.

Отже, у проведеній емпіричній серії занять для дітей створювалася така емоційно-пізнавальна діяльність, в якій пізнавальні психічні процеси набували афективного характеру. При виконанні ігрового та довільного (вольового) завдань у дітей, схильних до 1 типу реакцій, проявлявся інтерес до змістовного боку діяльності. При виконанні довільного (вольового) завдання діти орієнтувалися на реакцію психолога, що сприяло становленню соціально-значимої мотивації та дозволяло упоратися і з емоційними, і зі змістовними проблемами. Поступово якісне виконання завдань починало стимулювати дітей до продовження роботи, подолання труднощів та виходу із ситуацій неуспіху шляхом виправлення помилок. Виконання інтелектуального завдання переконливо довело не тільки важливість формування адекватних емоційних реакцій на успіх/неуспіх, але й самооцінки, яка фактично забезпечує стійкість цих реакцій. Важливо, що діти не сприймали ситуацію успіху якщо вона не співпадала із їхнім внутрішнім відчуттям цього успіху, а неуспіх не вів їх до відмови від подальшого виконання роботи і не викликав сильних негативних реакцій, коли не співпадав із внутрішніми очікуваннями.

Діти, схильні до другого типу реакцій при відносно легкому подоланні труднощів при виконанні завдань та переживанні неуспіху, при вирішенні довільного (вольового) завданні потребували більшої зовнішньої стимуляції. Вони орієнтувалися на реакції психолога, але довго залишалися пасивними та не виявляли зацікавленості. Момент першого виникнення позитивного емоційного відгуку виникав у них співпадав із активним пошуком виходу з ситуації неуспіху та подолання труднощів. В процесі виконання інтелектуального завдання при прийнятті ситуацій

Таблиця 1

Формування адекватних емоційних реакцій дітей із ЗПР на ситуації успіху/неуспіху при виконанні ігрових, довільних та інтелектуальних завдань

\begin{tabular}{|c|c|c|c|c|c|}
\hline \multicolumn{7}{|c|}{ Види занять } \\
\hline \multicolumn{2}{|c|}{ Ігрове } & \multicolumn{2}{|c|}{ Довільне (вольове) } & \multicolumn{2}{c|}{ Інтелектуальне } \\
\hline $\begin{array}{c}\text { Кількість } \\
\text { занять }\end{array}$ & Тип реакції & $\begin{array}{c}\text { Кількість } \\
\text { занять }\end{array}$ & Тип реакції & $\begin{array}{c}\text { Кількість } \\
\text { занять }\end{array}$ & Тип реакції \\
\hline 2 & 1 & $5-6$ & 1 & $5-6$ & 1 \\
\hline 4 & 2 & $8-10$ & 2 & $18-20$ & 2 \\
\hline
\end{tabular}


успіху/неуспіху вони переважно орієнтувалися на реакції психолога, а не на самооцінку. Вважаємо, що інтелектуальне завдання (усна лічба) для дітей із ЗПР з даним типом реакцій не сприяло становленню самооцінки та чітко диференційованого емоційного відгуку. Тому й ситуація штучного успіху викликала радість, а не здивування.

$\mathrm{У}$ дітей із реакціями 3 типу значні труднощі виникали при виконанні довільного (вольового) завдання. Зміст завдання викликав негативний відгук, зовнішня мотивація не була значимою, а навіть тимчасовий неуспіх провокував відмову від продовження роботи. Тільки різноманіття змісту завдань та тривала позитивна мотивація підтримували позитивні емоційні реакції на ситуації неуспіху у формі виправлення помилок. При виконанні інтелектуального завдання адекватні реакції на неуспіх були нестійкими, оскільки самооцінка у дітей ще не сформована. Страх неуспіху негативно впливав на продуктивність емоційної діяльності та, вірогідно, був пов'язаний із негативними очікуваннями.
Висновки і перспективи подальших розробок. Лонгітюдне формування адекватних емоційних реакцій у дітей із ЗПР дозволило виявити деякі індивідуально-психологічні особливості, які визначають продуктивність інтелектуальної діяльності та особливості взаємодії з дорослими. Важливим чинником, провокуючим негативні реакції, особливо у інтелектуальній діяльності, $\epsilon$ страх негативного емоційного очікування та основна корекційна робота має бути спрямована на його подолання. Позитивне очікування від ситуації може визначатися як змістовим боком, так і ступенем сформованості адекватних реакцій на неуспіх та способів виходу з нього. Важливим засобом закріплення досягнених результатів $\epsilon$ спільна $з$ дорослим робота та її обов'язкове завершення на позитивній ноті.

Оскільки дослідження є лонгітюдним, перспективи подальших наукових розвідок у цьому напрямку полягають у спостереженні за реакціями дітей цієї вибірки на ситуації успіху/неуспіху в умовах шкільного навчання.

\section{ЛІТЕРАТУРА}

1. Карабанова О. А. Развитие возрастно-психолгического подхода в современной психологии. Альманах института коррекционной педагогики. 2018. № 35 URL: https://alldef.ru/ru/articles/almanac-no-35/ the-development-of-the-age-a-psychological-approach-in-modern-psychology [in Russian]

2. Лубовский В. И. Психологические проблемы диагностики аномального развития детей. СПб: Питер, 2013. 245 с.

3. Прохоренко Л. І. Освіта осіб з особливими потребами: науково-психологічний супровід // Педагогіка і психологія. Вісник Академії педагогічних наук України. Київ, 2019. № 4. C. 25-34. URL: http://libtomcat.knute.edu.ua/library/DocDescription?doc_id=254368

4. Шванцара Й. Диагностика психического развития. Прага, 2017. 345 с.

5. Ziegler A. How desirable are gifted boys for girls and gifted girls for boys? Results of a chatroomstudy // Australasian Journal of Gifted Education. 2011. No 19. P. 16-20.

\section{REFERENCES}

1. Karabanova O. A. (2018). Razvitie vozrastno-psihologicheskogo podhoda v sovremennoj psihologii [Development of the age-psychological approach in modern psychology]. Al'manah Instituta korrekcionnoj pedagogiki. Al'manah № 35 URL: https://alldef.ru/ru/articles/almanac-no-35/the-development-of-the-agea-psychological-approach-in-modern-psychology [in Russian]

2. Lubovskij V. I. (2013). Psihologicheskie problemy diagnostiki anomal'nogo razvitija detej [Psychological problems in the diagnosis of abnormal development of children]. SPb: Piter. [in Russian].

3. Prokhorenko L. I. (2019). Osvita osib z osoblyvymy potrebamy: naukovo-psykholohichnyi suprovid [Education of people with special needs: scientific and psychological support]. Pedahohika i psykholohiia. Visnyk Akademii pedahohichnykh nauk Ukrainy. Kyiv. [in Ukrainian].

4. Shvantsara Y. (2017). Dyahnostyka psykhycheskoho razvytyia [Diagnostics of mental development]. Praha. [in Russian].

5. Ziegler A. (2011). How desirable are gifted boys for girls and gifted girls for boys? Results of a chatroomstudy // Australasian Journal of Gifted Education No 19. P. 16-20. 